Анђела Н. Реџић

Балканолошки институт САНУ

Београд
УДК 811.163.41’282.2 (497.115-12 Сиринић) https://doi.org/10.18485/uzdanica.2020.17.1.7

Оригинални научни рад

Примљен: 20. јануар 2020.

Прихваћен: 9. март 2020.

\title{
ГУБЉЕЊЕ ЈЕДНОГ ТАЈНОГ ЈЕЗИКА И ЊЕГОВА ИНТЕГРАЦИЈА У ЛОКАЛНИ ГОВОР
}

$A \bar{u} c \bar{u} p a \kappa \bar{u}:$ У раду се разматрају неке од особина и данашње функције бошкачког језика у шарпланинској жупи Сиринић. Материјал који чини основу рада прикупљен је у разговорима са житељима ове жупе. Од њих су такође добијени и неки ванлингвистички подаци. ${ }^{1}$ Мора се истаћи да се сада само отвара питање раслојавања језика и смештања обрађеног лексичког фонда (у који улазе и лексички дијалектизми) у ужу врсту социолекта. Испитују се, затим, функције традиционално везиване за тајне језике, конспиративна и демаркациона. Као једно од најзначајнијих питања у вези са целокупним прикупљеним материјалом истиче се његов опстанак и губљење, а њему се у раду приступа са стилистичког становишта будући да се ова лексика користи за стилизацију говорног израза, најчешће као маркер емоционализације, експресивизације или фамилијарног тона.

Кључне речи: тајни језик, бошкачки, функција, стилизација исказа, дијалектизми, губљење лексике.

Предмет рада је бошкачки језик и његова употреба у жупи Сиринић. Традиционално дефинисан као тајни језик занатлија или мајстора, бошкачки је раније обично као такав и истраживан, најчешће из лексичког и лексикографског угла. У овом раду ће бити посматран као један од слојева у лексичком фонду свих чланова локалне заједнице, будући да у њој данас нема чланова печалбара који бошкачки користе ван родног места и са конспиративном функцијом. Свакако, са нестанком примарних корисника и првобитне функције бошкачког језика, ради се о истраживању његових остатака и њихове интеграције у локални говор. Стога се прикупљен материјал обра-

\footnotetext{
${ }^{1}$ Разговори су за потребе мастер рада („Лексичко-семантичке и функционално-стилистичке карактеристике бошкачког језика", одбрањен на Филолошком факултету Универзитета у Београду) вођени са двема групама испитаника, првом која је садржала испитанике од око педесет година и другом са испитаницима у двадесетим.
} 
ђује са циљем да се утврди место остатака овог некадашњег тајног језика у једној заједници, као и да се испита сврха с којом се у говору употребљава. У вези са очувањем, односно опстанком бошкачког језика, за циљ је постављено и утврђивање чинилаца који су утицали на то да неке лексеме овог фонда опстану и чак прошире или трансформишу свој семантички опсег.

Бошкачки језик дефинише се као тајни занатлијски језик који су у прошлости користили печалбари ${ }^{2}$ претежно на територији њима оближњих села и градова, али који је широко распрострањен, па је забележен и у деловима Македоније и Бугарске, не само у јужнијим (југоисточним) крајевима Србије. „Тајни занатлијски језици ${ }^{3}$ представљају помоћна, секундарна средства комуникације којима су се служиле занатлије у међусобном споразумевању из којег је требало искључити 'непросвећене"' (Вучковић 2004: 2). ${ }^{4}$ Овај термин се „односи на социолект који се реализује искључиво на лексичком плану” (Вучковић 2004: 2), дакле бошкачки језик је језик само по звању; то је лексички фонд који се на свим језичким нивоима ослања на локални говор у којем се користи. Губљење тајних језика започето је и раније, не само у Сиринићу, већ и у другим територијама на којима се говори српски језик. Тако, Т. Ђорђевић, на пример, још 1900. констатује: „Тајним се језицима у Алексинцу данас готово нико не служи, али до пре 20-30 година били су још у употреби” (Ђорђевић 1900: 158).

Неке лексеме из бошкачког ипак и данас постоје у овом говору и оне би могле чинити део онога што Ризелова назива „широком базом колокви-

\footnotetext{
${ }^{2}$ У Сиринићу се не користи термин печалба, већ пошиење или, ређе, гурбе или гурбетлук. Питања гурбетлука су се истраживачи дотицали (исп. Јанковић Сречанин 1994: 5), док пошијење у досадашњим радовима није помињано, иако би се неки описи гурбетлука (нпр. у Никшић, Ђорђевић 1994: 105) могли изједначити са дефиницијом пошијења коју смо добили од испитаника, а оба би се могла свести на одлазак на рад у околна места. Пошиење је локални термини чије би се порекло могло објаснити двема претпоставкама. Прва је да је од предлошко-падежне конструкције са значењем намере по + акузатив (отишо по работе, нпр.), типичне за локални говор, настала лексема са номиналном вредношћу притом ширећи семантички опсег. Овако скован термин мајстори су прихватили од терзија с којима су често заједно путовали и у вези с којима се такође помиње тајни језик: „[...] протињавски је тајни језик терзија који су до недавно шили по разним местима Метохије, Косова и североисточне Албаније. [...] У протињавском многе су речи као у бошкачком и само је мали број речи другачији од речи у бошкачком. То су речи које су везане за прибор и алат терзија" (Бован 1972: 113). Друга је претпоставка да пошиење има везе са зидањем јер се сламени кров назива пошив, а прави се тако што се слама 'ушива' за даске помоћу жица (или неког другог материјала) и велике игле. И овакво објашњење је могуће јер се термин пошиење односи првенствено на зидаре печалбаре и сам појам одласка на рад у друго место, а не само на терзије који шију (и исто су тако ишли да ван свог места рођења траже посао).

${ }^{3}$ У литератури се за ову врсту социолекта користе и термини арго и тајни говори (в. детаљно у Вучковић 2004). Стојков социолекте попут бошкачког убраја у сленг, док термином арго назива „тайни говори на престьпниците” (Стојков 2008: 156).

${ }^{4}$ Данас у Сиринићу нема печалбара, па тако ни бошкачки не постоји као „тајни мајсторски језик".
} 
јалности” (Ризел, према: Симић, Јовановић 2002: 241), а за коју Јовановић и Симић наводе „чини је језичка грађа дијалеката и тзв. 'жаргона', 'социолеката' и сл." (Симић, Јовановић 2002: 241). ${ }^{5}$ Бошкачки бисмо условно сместили у социолекте „који одсликавају разлике између појединих друштвених целина у оквирима говорне заједнице [...] Овакве језичке разлике испољавају се најочигледније у лексици" (Радовановић 2003: 175), али уз напомену да тако дефинисан идиом улази заједно са изразитим лексичким дијалектизмима који обично имају синоним у стандарду 6 .

Даље о овој „бази” Симић и Јовановић наводе да дата грађа не би била „'лингвистичка база' свакодневности као целине, већ извесних њених појавних облика више интересантних са гледишта социологије језика него функционалне стилистике" (Симић, Јовановић 2002: 241), а посебну законитост језика свакодневнице виде у његовим функцијама (Ibid), па бисмо на основу тога истакли да је од највећег значаја истражити функције које овакав лексички скуп има. Истраживање са становишта социолингвистике било би такође корисно за откривање узрока како опстанка дела лексике бошкачког, тако и, с друге стране, његовог нестајања заједно с дијалекатском лексиком и уопште узрока промена у дијалекту.

\section{ФУНКЦИЈА И СТИЛИСТИЧКЕ КАРАКТЕРИСТИКЕ}

Овај се фонд данас, према нашем истраживању, налази на пола пута између жаргона и колоквијалног израза. Ту позицију дели са изразитим лексичким дијалектизмима који се обично осећају као архаизми и користе за експресивизацију или емоционализацију исказа. Б. Тошовић пише да су архаизми у разговорном језику ретки (Тошовић 2002: 401), али како се управо њиховом маркираношћу могу постићи емоционализација и експресивизација, које су у разговорном језику честе, бошкачки језик се заједно са поменутим дијалектизмима може за њега везати и даље посматрати у оквирима комуникативне ситуације.

Ценимо да је управо употребна вредност лексике један од разлога за њен опстанак. Наиме, у многим лексемама чија је мотивација и са синхроног становишта јасна препознајемо фигуративну (симболичку) метасемију код које се „два начела - близине и сличности - могу узети као темељ” (Симић 2001: 91), па тако, на пример, сличност, односно метафору можемо ви-

${ }^{5}$ Слично примећује Керемидчиева, везано искључиво за говор зидара севернородопског села Павелско у Хвојненској области (јужна Бугарска) (Керемидчиева 1995: 18).

${ }^{6}$ Према Б. Сикимић, на Косову и Метохији влада општа диглосија, па тако различите етничке групе свој стандард проналазе у удаљеним местима. „Србима, различитих дијалеката, лингвистички стандард је говор града Београда" (Сикимић 2010: 147-148). 
дети код секундарног значења лексеме $а љ, a$ - „тоалет” или тиква - „глава”, а близину, тј. метонимију у примеру као што је чураўник - „оџак”.?

\section{1. ФУНКЦИЈЕ БОШКАЧКОГ ЈЕЗИКА}

Истраживању смо приступили водећи се тиме да „за овај идиом више не важи ни одређење тајни ни занатлијски" (Вучковић 2015: 181). У сваком случају, овде се желимо посветити одређењу тајни, тј. конспиративној функцији. Бошкачки језик данас нема ову функцију када је реч о комуникацији унутар истраживане заједнице. Лексика је свима позната.

Међутим, како информатори рођени после времена печалбара кажу, некада су и они овакве лексеме користили да сакрију садржај од неупућених, односно од оних који не познају или слабо познају локални говор. Када би им у време када су били деца долазила родбина из других крајева, употребљавали би бошкачки да своје вршњаке из различитих разлога искључе из разговора. Оваква употреба је и данас активна, што се види из приче једног од испитаника који је послом често у Новом Саду, где борави заједно са колегама из Сиринића, али и из других крајева. Он наводи да некад у друштву оних који „не знају нашки” с људима из Сиринића користи бошкачки у конспиративне сврхе и даје пример: „онај лизгач јопе мьглоса по рано” - „онај пијанац је опет побегао раније”. Из примера се види да конспиративну функцију не врши само бошкачки, односно лексика која га чини, већ и маркантне дијалекатске црте које говорницима других дијалеката такође у одређеној мери онемогућавају разумевање (у конкретном примеру дијалекатски лик прилога опет, глагол мьглошем ${ }^{8}$ ( „побећи, изгубити се") и аналитички компаратив прилога по рано).

Када је реч о истраживању тајних језика, заједно с њиховом конспиративном функцијом помиње се и демаркациона која ,,језичке заједнице и њихове језике раздваја од других заједница и језика" (Бугарски 1986: 232). С обзиром на данашњи статус лексике из бошкачког, рекли бисмо да се и ова функција унеколико активира у претходно описаним ситуацијама. Ипак, и сам бошкачки се не користи увек, већ искључиво у кругу познатих и блиских људи. Такође, врло ће ретко бити употребљена нека лексема из бошкачког у разговору особа удаљених по годинама. У другим приликама бошкачки је показатељ блискости саговорника. Иако је познат свим говорницима локалног дијалекта у одређеној мери, не користе га у разговору са себи мање познатим људима. Овде, дакле, видимо неке од особина жаргона

\footnotetext{
${ }^{7}$ Метафора и метонимија се такође наводе и као чест начин формирања лексике и у бањачком (тајном језику осаћких мајстора) (Шћепановић, Ђукановић 1997: 137-140).

${ }^{8}$ У Сиринићу нема инфинитива, стога глагол наводимо у 1. л. јд. презента.
} 
у ширем смислу које наводи Р. Бугарски: „Широко говорећи, жаргоном се може назвати сваки неформални и претежно говорни варијетет неког језика који служи за идентификацију и комуникацију унутар неке друштвено одређене групе - по професији, социјалном статусу, узрасту и слично - чије чланове повезује неки заједнички интерес или начин живота [...]" (Бугарски 2003: 9).

М. Вучковић у вези с бошкачким пише о бошкачком као симболу локалног идентитета (Вучковић 2015: 186-190) и улози бошкачког аргоа у изградњи бошњачког идентитета словенских муслиманских група на југу Косова и Метохије (Вучковић 2015: 190-202). Друго наведено нема никаквог значаја за нашу тему јер у Сиринићу нема људи који се идентификују као Бошњаци и они који су чули за бошкачки препознају га као свој, сву лексику идентификују као нашку, тј. своју. Када је реч о виђењу бошкачког као симбола локалног идентитета, такође не бисмо могли рећи да такву улогу има у Сиринићу ни у једној од старосних група. Употреба бошкачког би се могла посматрати као таква уколико се Сиринићани нађу ван родног места, мада и тада он сам неће бити посебан симбол, већ ће, интегрисан у локални говор, имати својеврсну идентификациону улогу. То јест, у комбинацији са дијалектизмима и месним граматичким системом, бошкачки се може посматрати и као симбол локалног идентитета.

\section{2. СТИЛ КАО УЗРОЧНИК ОПСТАНКА И ПРОМЕНЕ ЛЕКСИЧКОГ ФОНДА}

Иако се и даље изучава под термином тајни језик, бошкачки данас нема конспиративну функцију. Међутим, из прилика у којима се лексика из бошкачког користи, из начина на који се препознаје, као и из тога какав однос према њој имају говорници, види се да се она у локалном говору ипак не употребљава без икаквих специфичних обележја. Она углавном служи као средство стилизације (за постизање експресивног или фамилијарног тона) онда када се посеже за лексемом која има еквивалент у дијалекту или чак у стандарду, а која нема значајну конотацију, нпр. лојаўка ${ }^{10}$ - „свећа”,

\footnotetext{
${ }^{9}$ Употребу бошкачког у сврху учвршћивања бошњачког националног идентитета у неколико новинских чланака помиње и Рамиз Шаипи Имер, али о његовом раду на овом аргоу, осим у поменутим чланцима, као ни о њему нисмо успели ништа више пронаћи (на основу изборне претраге на сајту cobiss.com, на сајту academia.edu и интернет претраге).

${ }^{10}$ Лексема лојаўка изузетно је честа у локалном говору, захваљујући животним приликама и потреби да се синоними десинонимизирају. Наиме, због честих рестрикција струје, свеће се у Сиринићу и даље доста користе, па се лојаўка раширила у општој употреби у значењу бела свећа од парафина која се користи у кући да би се направила разлика у односу на свећу која означава воштану свећу која се пали у иркви и на гробљу.
} 
sурка - „вода”, благалак - „слаткиши”, ђомка - „(чорбаста) храна”. Оваква, експресивна функција најчешће се и наводи у вези са бошкачким, односно с некадашњим тајним језицима. ${ }^{11}$ Неке лексеме опстале су и из потребе за језичким средством за именовање не само одређених појмова, већ појмова са прецизно утврђеним карактеристикама, као што је, на пример, случај са лексемом крља. Основно значење у вези је са дрветом, и то не било каквим. Денотат је доста спецификован: то дрво је дебело, непогодно за обраду, пуно чворова и/или старо и труло дрво. На основу тог значења настало је и значење „слаб, неразвијен човек”. С друге стране, ова се лексема у зависности од контекста може употребити и да означи било шта лошег облика, нпр. „сипи воду у туј крљу” (шољу/чашу необичног (и по оцени говорника ружног) облика или окрњену, напрслу). ${ }^{12}$ Ово је пример за, с једне стране, специјализацију значења, али и, с друге стране, за уопштавање. ${ }^{13}$

Код промене значења не можемо навести један узрок или неколико њих јер је промена обично резултат неколико фактора који се преплићу. Могло би се говорити о комбинацији хомонимије и утицаја онога за шта говорници дијалекта сматрају да спада у уобичајени српски језик ${ }^{14}$. Тако лексема кучка, која према старијим испитаницима у бошкачком значи „машна” ( кравата, тј. комад одеће који се носи око врата), за млађе је искључиво „лоша, безобразна жена”. Такође, за лексему клинка кажу „па једино оно као девојчица, али то није наше”, док за туц̧а се знају нашко значење - „лута се, шета бесциљно", али избегавају да реч употребе и имају потребу да направе дистинкцију због значења ове речи из жаргона које је опсцено, а распрострањеније је у говору млађих. Старији пример хомонимије која је омогућила превагу другог идиома у односу на бошкачки је лексема кромид за коју сви испитаници кажу да значи искључиво „црни лук”, како је у локалном говору, иако је некада у бошкачком који се користио у овом крају имала значење које се наводи у литератури - „часовник” (Вучковић 2004: 168).

\footnotetext{
${ }^{11}$ „Утратив свою основную, конспиративную функцию, эти 'языки' держатся своей второй экспресивной функцией” (Бондалетов 1974: 19).

12 У Сиринићу постоји и лексема крндељ са значењем „чворноват пањ, тежак за сечење”, сличним оном које има и крља. Због блискости значења, крља би могла означавати и појам подразумеван под лексемом крндељ, па је тако потоња лексема много ређа и потиснута у употребу у дискурсу везаном за обраду дрвета. Управо из ових разлога она нема једнако развијено секундарно значење.

${ }^{13}$ Овакве појаве у значењу лексема из тајних језика примећује и Воденичаров: „Функционална татрансформация на говора е довела до модифициране както на денотативно, така и на конотативно значение на наследните лексикални единици. Голяма част от лексемите со развили своето денотативно значение в посока към неговото разширяване и пейоративно обособяване" (Воденичаров 1988: 24).

${ }^{14}$ Овде се не користимо термином стандард или књижевни језик због примера који су заправо на маргинама или су такође стилски маркирани, а обично припадају жаргону.
} 
Има и примера у којима нема хомонимије. Ценимо да су управо они важни показатељи развојног пута бошкачког, можда и његовог губљења. За баљко и баљошко добили смо различите одговоре од испитаника у млађој групи, један изузетно прецизан - „шарен пас”, а други у виду нагађања ,да није будала", који се односио и на баљоико. Разлог за први одговор је у томе што је особа велики љубитељ и познавалац паса, а за други вероватно гласовни састав и семантика форманата (посебно због делова -ко и -ошко) и управо својеврсна свест о тематским и стилским оквирима употребе ове лексике. Такође, узрок је и промена живота: волова готово да и нема, паса има доста. Што се значења „пита” (,врста пецива од наслаганих или увијених кора”) тиче, сећају га се старији испитаници, али с одређеним напором. Будући да се не наводи да је лексема баљоико означавала неку посебну врсту пите или карактеристику у вези с питом, она је у овом значењу вероватно постојала као синоним за питу неко време, па је у том значењу потиснута. Постоји и овакав новији случај. Млађи испитаници у лексеми лазарка (у бошкачком значи „година”) виде искључиво назив за учеснице у обичају ${ }^{15}$ јер је тај обичај и даље жив, али и због тога што је мотивација јасна: лазарке због Лазареве суботе, док између фонетског и семантичког састава лексеме лазарка и лексеме и појма године са синхроног становишта нема асоцијативне везе. Такође, лексему фрчула млађи препознају као пасуљ, али са тешкоћом и маркирају је као врло стару (М. Вучковић наводи да је ова лексема у бошкачком позајмљеница из грчког, претпостављајући на основу фонетике да је ту доспела посредством албанског. Као део инвентара бошкачког бележе је и Поленаковиќ (1951: 53), Ховенберг, Марков (1955: 16), Никшић, Ђорђевић (1994: 106), Јанковић (1994: 29), Бован 1972: 130)).

За разлику од претходно наведених, за лексему гура смо од најмлађе групе чули и једно ново значење гура с некога ,бити с неким у емотивној вези”. У бошкачком овај глагол значи „ићи”, а он сам, као и његово значење, у вези су с лексемом из бошкачког гуравка, која значи „нога”. У Сиринићу се обично за особе у емотивној вези каже да иду или за неког да иде c юу/

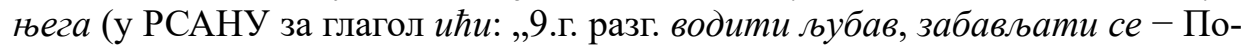
верила се другарици да иде са тим младићем"). На лексему из бошкачког гура пресликано је секундарно значење (као и рекција уз одговарајуће значење) глагола $u \hbar u$. Ово је, дакле, случај пресликавања фрагмента семантичке структуре једног синонима на други и, што је можда још значајнији индикатор интеграције, смер ,позајмљивања” није из бошкачког у локални говор, већ обрнуто. Између лексема иду и гуру ипак постоји стилска разлика (и управо захваљујући њој опстаје потоња): иду је неутрално, а гуру експресивно и може бити са ироничним призвуком.

${ }^{15}$ Обичај на Лазареву суботу да девојчице обучене у народну ношњу иду по селу и певају лазаричке песме за шта их домаћини награђују јајима и новцем. 


\subsection{1. ГУБљЕЊЕ ЛЕКСЕМА}

„Стварни и најчешћи узрок практичне дисфункције у свим културама - јесте застаревағе. С променом људских потреба, услова рада и технолошких поступака, из производње 'испадају' читава брда направа, алата и машина" (Симић 2001: 82). Управо због нестанка реалија нестају и лексеме. Верујемо да смо заправо и забележили процес дисфункције знака у тренутку док се дешава, чувши од информатора да су, на пример, чули реч совељка - „висока мршава жена” (Вучковић 2004: 259) или sиўкос (sифкос) - „бекство” (Вучковић 2004: 306) и да им је „на врх језика” шта је, али се не могу сетити шта значе. Затим, добијали смо и несигурна објашњења попут „требало би да је некаква спојнииа" за лексему кушак. У вези с лексемом лингурка $a^{16}$ испитаници су нагађали „да није можда луталица”, једнако као и за лексему котлосан - ,а није пијан?”.

Један од узрочника нестанка лексике је свакако и језичка економија, и то пре свега у односима синонима. Речено се објашњава на примеру лексема из бошкачког које се односе на неморалне радње, најчешће на лаж, крађу и преваре. Ово је једина тематска група која чува синониме у којима нема ни стилских разлика, па тако левоше значи „краде”, смути и мафma могу значити и „лаже” и „краде”, а скурошуе значи само „лаже”. Оно што примећујемо подједнако у вези са свим лексемама овде је губљење разликовних нијанси у значењу, уопштавање и одношење на нешто уопште негативно или нечасно, као и недовољно јасно значење. Захваљујући том уопштавању, лексеме из ове тематске групе прво почињу да шире свој семантички опсег, прихватајући притом и значења неке од осталих лексема из те групе, али мање спецификовано. У следећој фази остаје већи број лексема које се могу употребљавати у истом значењу, а које ће нешто конкретније нијансе остварити у контексту. Затим, те лексеме постају синоними и неумитно неки од њих испадају из употребе. Друга страна овог процеса јесте учвршћивање позиције оног синонима који опстане због тога што има богатију полисемантичку структуру.

\footnotetext{
${ }^{16}$ Нагађање наших информатора у вези са овим значењем било је заправо присећање на конотацију коју је та реч некада имала. Наиме, средња група присећа се некадашњих времена које Р. Младеновић објашњава на следећи начин: „Социјална позиција Лингураца на широком балканском простору је да су кашикари и коритари, а етничка Цигани. [...] Лингур [je] погрдан назив за Рома са пејоративном нијансом да је то скитница. И у самом Сиринићу у употреби је апелатив лингур са значењем скитнииа" (Младеновић 2006: 108).
} 


\section{ЗАВРШНА РАЗМАТРАњА}

Дефиниција бошкачког као тајног језика је питање чувања некадашње терминологије, будући да се заправо од губитка његове конспиративне функције о бошкачком може говорити као о специјалном лексичком фонду. Такође, и онда када су били тајни, ови ,језици” нису имали своју граматичку структуру, већ су се у потпуности ослањали на језик којим иначе говоре његови корисници. Иако је, такође, у вези с бошкачким раније помињано да нестаје или да је чак нестао, он данас и даље постоји, али изворни говорници дијалекта лексемама бошкачког не придају посебно место у односу на изразите лексичке дијалектизме, већ их од њих не разликују.

Конспиративна и демаркациона функција, супротно очекиваном, данас нису у потпуности ишчезле, већ се могу потенцијално активирати под условом да се истраживани лексички фонд користи ван граница Сиринића, и то у комбинацији са његовом граматичком структуром која осталим говорницима српског језика такође отежава разумевање. Као најзначајнија данашња функција „тајних језика” наводи се експресивна и она је овде присутна, поготово када су у употреби лексеме које имају еквивалент у стандарду. Често се у овим приликама може препознати и емоционализација исказа.

На опстанак једног дела лексике свакако утиче и потреба за именовањем специфичних појмова или ентитета, поред већ помињане потребе за стилизацијом исказа. Очекивано, и овај лексички слој се мења и као главни узрочник данашњих промена може се навести утицај стандарда на дијалекат. Када је реч о нестајању (дијалекатске) лексике, очигледно је да је овај процес снажан и да се може јасно видети на примерима из бошкачког. Узрочници су овде многи, пре свега нестајање реалија, затим језичка економија, али и ставови према језику, којима се треба посветити посебна пажња.

\section{ЛИТЕРАТУРА}

Андрић (2005): Драгослав Андрић, Двосмерни речник срйской жарїона и жаріона срояних речи и израза. Београд: Zepterbookworld.

Бован (1972): Vladimir Bovan, Tajni jezici radnika Sredske i Sirinića, Гласник музеја Косова (и Мейохије), XI (1971-1972), Приштина, 113-131.

Бондалетов (1974): Василий Д. Бондалетов, Условные языки русских ремесленников и торговцев. Условные языки как особый тип социальньх диалектов, Рязань.

Бугарски (1986): Ranko Bugarski, Jezik i društvo, Beograd: Prosveta.

Воденичаров (1988): Петр Воденичаров, Езиково взаимодействие в един таен говор (говора на слепците-просяци от село Добърско, Разложко), Съпоставително езикознание XIII/2, София, 23-26. 
Вучковић (2004): Марија Вучковић, Бошкачки - тиајни језик зияара Среgске и Сиринића, магистарски рад у рукопису одбрањен 8. 7. 2004. године, Филолошки факултет Универзитета у Београду (ментор: др Биљана Сикимић, чланови комисије: проф. др Радојица Јовићевић, проф. др Драгана Мршевић-Радовић, проф. др Првослав Радић).

Вучковић (2015): Марија Вучковић, Нове улоге бошкачког аргоа, у: М. Ковачевић, В. Поломац (ред.), Пуйевима срйских ияиома: зборник у часй йроф. Раgивоју Млаgеновићу йовоgом 65. рођенgана, Крагујевац: Филолошко-уметнички факултет, 181-205.

Драгићевић (2010): Рајна Драгићевић, Лексиколоіија срӣской језика, Београд: Завод за уџбенике.

Ђорђевић (1900): Тихомир Ђорђевић, Белешке о тајним језицима (у Алексинцу), Карацић, II/8-9, Алексинац, 156-164.

Имер (2013): Ramiz Šaipi Imer, Boškački - tajni govor majstora sa Kosova, преузето 13. 10. 2019. са сајта https://www.dw.com/sr/bo\%C5\%A1ka\%C4\%8Dki-tajni-govor -majstora-sa-kosova/a-17089433.

Имер (2016): Ramiz Šaipi Imer, Boškački govor (argo) - tajni govor majstora, преузето 13. 10. 2019. са сајта https://www.balkanplus.net/prof-amiz-saipi-imer boskacki -govor-argo-tajni-govor-majstora/.

Јанковић (1994): Слободан Јанковић Сречанин, Бошкачки језик са речником, Срецка: Основна школа „Срецка” у Срецкој.

Керемидчиева (1995): Славка Керемидчиева, Говорьт на павелските майстори зидари, Проглас 3, Велико Трново.

Младеновић (2006): Радивоје Младеновић, Романски трагови у ономастици северношарпланинских говора, Проблеми словенске фблолоіије, XIV, Timişоаra: Universitatea de Vest, 99-116.

Никшић, Ђорђевић (1974): Александар Никшић, Богољуб Ђорђевић, Бошкачки речник средачких зидара Апсика је скопаче (Лепо је девојче), Сйремљењ $а$, 8/10, Приштина.

Поленаковиќ (1951): Харалампије Поленаковиќ, Прилози кон македонските тајни јазици, Макеgонски јазик, II/3-4, 49-57.

Радовановић (2003): Милан Радовановић, Социолонйвисииика, Нови Сад: Издавачка књижарница Зорана Стојановића.

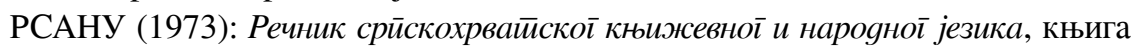
VIII, Београд: Институт за српскохрватски језик

Сикимић (2010): Биљана Сикимић, Лингвистичка реалност Косова: диглосија и

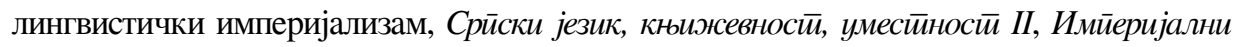
оквири књижевностии и кулитуре (ур. Драган Бошковић), Крагујевац: ФИЛУМ, 143-152.

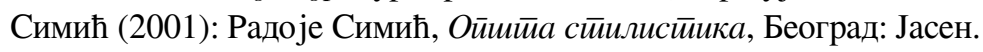

Симић, Јовановић (2002): Радоје Симић, Јелена Јовановић, Основи тиеорије функционалних сииилова, Београд: Јасен. 
Стојков (2008): Славко Стойков, Българските социални говори, Избрани езиковедски трудове, София: Университетско изделателство „Св. Климент Охридски”, 155-169.

Тошовић (2002): Бранко Тошовић, Функционални сииилови, Београд: Београдска књига.

Ћирић (2018): Љубомир Ћирић, Речник іовора Лужнице, Београд: Српска академија наука и уметности и Институт за српски језик САНУ.

Ховенберг, Марков (1955): Х. Ховенберг, Б. Марков, Прилог кон тајните јазици, Макеgонски јазик, VI/1, 4-21.

Шћепановић, Ђукановић (1997): Михаило Шћепановић, Петар Ђукановић, Бањачки (тајни језик осаћких мајстора), Срйски језик, II/1, 131-151.

\author{
Anđela N. Redžić \\ Serbian Academy of Sciences and Arts \\ Institute for Balkan Studies \\ Belgrade
}

\title{
THE LOSS OF A SECRET LANGUAGE AND ITS INTEGRATION INTO A LOCAL LANGUAGE
}

Summary: This paper deals with the characteristics and present-day functions of boshkachki, the secret language used by the craftsmen from the district of Sirnic, in the Sharr Mountains, who used to work as seasonal workers, usually in the surrounding territories. Although it is called a secret language, in fact boshkachki has never been a language in the real sense of the word; it is rather a lexical fund that was completely embedded in the language used by the local speakers. Nowadays there are no craftsmen who work as seasonal workers, but the lexical fund still exists within the district, in spite of being used less and less. Almost every member of the community knows some of the words and uses them, but only those over fifty years old know that it was once used as a secret language. However, even they do not distinguish these words from the ones they recognise as a part of the local language.

The aim of this paper is to examine the surviving traces of this secret language. The research material was provided by interviewing the district's inhabitants. Some nonlinguistic data were collected for the purpose of the research as well.

The paper only touches on the question of the stratification of language and placing the lexical fund in a more specific type of a sociolect. The functions which are traditionally contributed to secret languages, conspiratorial and demarcating, were analysed. One of the most important issues, which concerns the survival and disapearing of the boshkachki, was analysed from the stylistic point of view, since its lexicon is commonly used as a marker of emotionalization, expressivity or informality.

Key words: secret language, boshkachki, language functions, stylistics, dialectism, disappearing of lexicon. 